Journal of Social Sciences 4 (4): 280-287, 2008

ISSN 1549-3652

(C) 2008 Science Publications

\title{
Efficiency Comparison of Operational and Profitability: A Case of Hong Kong Commercial Banks
}

\author{
Cheng-Ru Wu, Hui-Yin Tsai and Ya-Mei Wang \\ Institute of Business and Management, Yuanpei University, \\ 306 Yuanpei St., Hsin Chu 30015, Republic of China, Taiwan
}

\begin{abstract}
Problem Statement: Traditional DEA models deal with measurements of relative efficiency of DMUs regarding multiple-inputs vs. multiple-outputs. One of the drawbacks of these models is the neglect of intermediate products or linking activities. The objectives of this study were: (i) This research was shown how to use DEA by two stages, with outputs from the first stage becoming inputs in the second stage. (ii) Comparative analysis of efficiency of bank manageable in Hong Kong. Approach: The research conducts a comparative analysis of efficiency of bank manageable in Hong Kong using a two-stage model, which evaluates their Operational Efficiency (OE) and Profitability Efficiency (PE). The study period covered 2004-2006 and used two-stage Data Envelopment Analysis (DEA). Results: Large-sized banks are generally more efficient than smallsized ones in the operational efficiency; while small efficient banks are easily to become benchmarks, large efficient banks are deemed as competitive niche players. This means that the large banks have better competitive power than those of smaller ones. Conclusion: Using this model, we can evaluate divisional efficiencies along with the overall efficiency of decision making units (DMUs).
\end{abstract}

Key words: Date envelopment analysis, stock exchange, Over The Counter (OTC), two-stage, operational efficiency, profitability efficiency

\section{INTRODUCTION}

The Hong Kong had a long tradition of being a laissez-faire economy and has committed to maintaining the free market stance since its sovereignty was returned to China in 1997. As a major international financial center in Asia and as a gateway to mainland China, Hong Kong has a very high density of financial institutions and that is characterized by its high degree of internationalization, business-friendly environment and comprehensive financial network, sophisticated support services. Because of the globalization effect, the competition among worldwide financial corporations is more and more serious. Therefore, they will play a major force in financial services industry and to analyze the advantage of the banks in Hong Kong and the optimal efficiency. However, the Hong Kong bank is none other than the pursuit of a greater scope of business and the generation of more profit. Thus, in facing a highly competitive environment, the formulation of a competitive strategy, the strengthening of corporate operations and the upgrading of the quality of service have become essential for survival. In formulating competitive strategies, one major problem is the measurement of management performance in the industry, prior to an assessment of advantages and disadvantages. Another problem that is encountered is the determination of factors that affect managerial efficiency.

Based on two-stage Data Envelopment Analysis (DEA) we used multiple inputs and outputs to measure the managerial efficiency of the banks. This analysis used the two stages of Operational Efficiency (OE) and Profitability Efficiency (PE) to compare the banks performance. We investigated and analysed the efficiency differences based on different characteristics of the firms and compared the efficiency of older banks with newer banks, as well as any differences in efficiency based on the size of the banks. In addition, management performance was not restricted to production efficiency or cost minimization, but was a more general assessment, involving management and marketing services and sales. However, banks provide financial services through the use of a non-price competition model to meet the needs of customers with high quality services. The development of a bank's investment portfolio will help the banks overall operating performance.

Based on the measurement of managerial efficiency, a management decision matrix was

Corresponding Author: Cheng-Ru Wu, Institute of Business and Management, Yuanpei University, 306 Yuanpei St., Hsin Chu 30015, Republic of China, Taiwan 
developed to serve as the basis for an assessment of the competitive strategy of the eighteen banks in Hong Kong. This will aid each bank in the industry to gain a greater understanding of the gap between the banks and improve their operational efficiency by providing future operational strategies through analysis. Finally, this research will provide conclusions, recommendations and follow-up research proposals.

Literature review: Because there are many applications of the data envelopment analysis method given in the literature, this study focused only on those that discuss the operating efficiency of a bank. There have been several articles published in journals on the use of DEA in determining efficiency levels in the banking industry. The efficiency approach has been applied to numerous settings over several years, including the financial services sector. Seiford and $\mathrm{Zhu}^{[14]}$ first suggested using the two-stage DEA method to divide a commercial banks production process into two stages, marketability and profitability. Subsequently, Lu and Lo ${ }^{[7]}$ used DEA with a two-stage production process that included profitability and marketability performance. In addition, Luo ${ }^{[8]}$ applied DEA to a sample of 245 large banks. This study provided evidence that large banks were achieving relatively low levels of marketing efficiency. There were 34 banks (about 14\%) that achieved high levels of profitability performance, but low levels of marketing performance. The results also indicated that the geographical location of the banks did not seem to be related to either the profitability or marketability efficiency levels.

The Overall Technical Efficiency (OTE) of the profitability performance may predict the likelihood of bank failure. Manandhar and Tang ${ }^{[10]}$ combined the service-profit chain into their research model and reached the conclusion that the profitability of a firm will ultimately increase when a firm improves the quality of the service delivered to customers. This is because good service quality will have good effects on customer satisfaction and thus indirectly have a positive influence on profitability. Chen ${ }^{[3]}$ assessed the management performance of banks in Taiwan, incorporating operating efficiency, marketing efficiency and financial achievements in the study. The results of this research showed significant differences with the pre-calculated efficiencies. Banks in public ownership exhibited superior profitability performance; whereas privately owned banks tended to perform better with regard to operational capabilities. Furthermore, the relatively large banks exhibited superior performance on profitability; whereas the smaller banks tended to perform better with regard to operational capabilities. Halkos and Salamouris ${ }^{[5]}$ explored the efficiency of
Greek banks using a number of suggested financial efficiency ratios and found that the banks with the largest total assets had the highest efficiency levels. Wide variations in performance showed that increases in efficiency accompanied increases in the size of banks due to mergers and acquisitions. $\mathrm{Zhu}^{[17]}$ used the DEA method to calculate the efficiency of 364 companies and found that top-ranked companies in terms of revenue do not necessarily hold the top performance rankings for profitability and marketability. Numerous other studies have also used the DEA method, including ${ }^{[4,6,9,11,12]}$. In addition, Sathye ${ }^{[13]}$ offered the important conclusion that government deregulation and the leadership strategies of merging banks provided operations with significant impact.

\section{MATERIALS AND METHODS}

The intermediation approach treats banks as intermediary bodies, were non-depository account offer businesses financial resources, which they may borrow against in the form of business loans, in order to make a profit. Thus many lenders invest their money through banks, investing for the duration of projects by paying various costs, such as costs, interest charges and the cost of funds for projects, in which banks have invested. Most scholars have used the intermediation approach because the project is relatively easy to calculate, the information is easily obtained and it can show the bank's asset by type, size differences and multiple output characteristics. However, it should be noted that the definition and measurement of bank inputs and outputs has long been debated among researchers and there is no definite, commonly agreed choice $^{[13,16]}$. This study adopted the intermediation approach for definition of input and output variables. In this study we measured managerial efficiency in twostages, Operational Efficiency (OE) and Profitability Efficiency (PE). These types of efficiency are respectively based on the two-stage service provision process, which describes two essential departments of bank operations. This research was divided into two stages with six factors being expressed as inputs and outputs in each stage.

The first stage addressed the measurement of marketing efficiency, a bank's ability to generate output in terms of its current personnel expenses and operating expenses, using data based on 2004-2006 yearly average values. The input and output data were extracted from the Taiwan Economic Journal (TEJ) data bank. The TEJ data bank is commonly deemed valid, reliable and available to the public. Thus, the operational efficiency model had the following two output variables, Other Income and Interest Revenue. The second stage measured profitability efficiency with 
J. Social Sci., 4 (4): 280-287, 2008

\begin{tabular}{|c|c|}
\hline Outputs & Outputs \\
\hline$\{\begin{array}{l}\text { Total deposits } \\
\text { Gross Loans }\end{array} \overbrace{\text { Interest Revenue }}^{\text {Other Income }}$ & $\begin{array}{l}\text { Other Income } \\
\text { Interest Revenue }\end{array} \Rightarrow \begin{array}{c}\text { Pre-Tax Income } \\
\text { Total Assets }\end{array}$ \\
\hline Stage I: Operational efficiency & Stage II: Profitability efficiency \\
\hline
\end{tabular}

Fig. 1: Banks inputs and outputs in production process

input in terms of its current Interest Other Income and Interest Revenue, the profitability efficiency model has two outputs: Pre-tax income and total assets. Two-stage were as follows:

\section{Stage I: (Operational efficiency):}

Input factors:

- Total Deposits: Including customer contacts and savings

- Gross Loans: The bank's customer gross loans for sum of money

\section{Output factors:}

- Other Income: Including net commission, securities trading, foreign exchange trading, dividend income and rental income

- Interest Revenue: Including the interest income from loans

\section{Stage II: (Profitability efficiency):}

Input factors:

- Other Income: Including net commission, securities trading, foreign exchange trading, dividend income and rental income

- Interest Revenue: Including the interest income from loans

\section{Output factors:}

- Pre-Tax Income: The net profit not deduction the income tax

- Total Assets: These variables include: current assets, long-term investment, fixed assets and other assets

Form Fig. 1 the operational performance model (stage I) measured a banks ability to generate revenue, which consisted of two inputs (Total deposits and gross loans) and two outputs (Other income and interest revenue). The profitability performance model (stage (II) measured a banks attractiveness, in two inputs (Other income and interest revenue) and two outputs (Pre-tax income and total assets). The output and input factors used in this study were as follows. Relevant information input and output, respectively, are shown in Table 1 and 2.

This study used the data based on 2004-2006. The input and output data were extracted from the Taiwan Economic Journal (TEJ) data bank. The TEJ data bank
Table 1: presents the descriptive statistics for our data set

\begin{tabular}{lllll}
\hline Factors & Mean & SD & Minimum & Maximum \\
\hline $\begin{array}{l}\text { Total } \\
\text { deposits }\end{array}$ & $823,267,756$ & $1,509,298,157$ & $6,072,005$ & $5,754,857,000$ \\
$\begin{array}{l}\text { Gross } \\
\text { loans }\end{array}$ & $503,454,884$ & $930,595,100$ & $6,836,708$ & $3,542,824,000$ \\
$\begin{array}{l}\text { Other } \\
\text { income }\end{array}$ & $5,228,926$ & $7,429,431$ & 180,487 & $28,505,667$ \\
$\begin{array}{l}\text { Interest } \\
\text { revenue }\end{array}$ & $37,203,243$ & $63,860,405$ & 986,754 & $239,344,000$ \\
$\begin{array}{l}\text { Pre-tax } \\
\text { income }\end{array}$ & $11,680,653$ & $18,189,362$ & 334,554 & $63,167,333$ \\
$\begin{array}{l}\text { Total } \\
\text { assets }\end{array}$ & $990,116,781$ & $1,680,195,600$ & $11,000,499$ & $6,344,735,333$ \\
\hline
\end{tabular}

Table 2: Correlation coefficients among inputs and outputs

\begin{tabular}{lcccccl}
\hline Factors & $\begin{array}{l}\text { Total } \\
\text { assets }\end{array}$ & $\begin{array}{l}\text { Gross } \\
\text { loans }\end{array}$ & $\begin{array}{l}\text { Other } \\
\text { income }\end{array}$ & $\begin{array}{l}\text { Interest } \\
\text { income }\end{array}$ & $\begin{array}{l}\text { Pre-tax } \\
\text { income }\end{array}$ & $\begin{array}{l}\text { Total } \\
\text { deposits }\end{array}$ \\
\hline $\begin{array}{l}\text { Total } \\
\text { deposits }\end{array}$ & 1 & & & & & \\
Gross & 0.997 & 1 & & & & \\
loans & $(0.000)$ & & & & & \\
Other & 0.531 & 0.474 & 1 & & & \\
income & $(0.023)$ & $(0.047)$ & & & & \\
Interest & 0.994 & 0.985 & 0.607 & 1 & & \\
income & $(0.000)$ & $(0.000)$ & $(0.008)$ & & & \\
Pre-tax & 0.974 & 0.960 & 0.658 & 0.984 & 1 & \\
income & $(0.000)$ & $(0.000)$ & $(0.003)$ & $(0.000)$ & & \\
Total & 0.996 & 0.987 & 0.601 & 1.000 & 0.984 & 1 \\
assets & $(0.000)$ & $(0.000)$ & $(0.008)$ & $(0.000)$ & $(0.000)$ & \\
\hline
\end{tabular}

is commonly deemed valid, reliable and available to the public.

The descriptive statistics of the inputs and outputs in each DEA stage are reported in Table 1. For example, the mean of total deposits was approximately NT\$ 823 billion in the sample. In addition, the minimum was approximately NT\$334,554 and the mean was NT\$11,680,653 for Pre-Tax Income. This study used input variables and output variables to Pearson correlation verification, analysis inputs and outputs between the variables related to the degree to avoid the improper admission of variables, which will affect results are correct. Correlation analysis results as a Table 2, the correlation coefficients were related to a certain extent.

DEA methodology: According to the concept of efficiency for performance evaluation method, the main comparison was between the input-output relations. DEA efficiency assessment model used envelope line technology to replace the general economics of individual production function, whose basic theory was based $^{[3]}$, from the concept of technical efficiency. Three scholars ${ }^{[2]}$ expand the single input single output model into the concept of multiple inputs-multiple output to create a form used to assess the decision-making units Decision Making Unit (DMU) relative efficiency, 
which can use non-identical units for a number of inputs and outputs various renovation to a single value, which was obtained for a value prefecture institutions organizational efficiency, commonly known as CCR model. This study used methods for measuring efficiency levels of data envelopment analysis; CCR model to measure the Decision-Making Units (DMU) operating efficiency, its theoretical description is as follows ${ }^{[2]}$ : Pursuant to ${ }^{[3]}$ to assess the efficiency of the theoretical basis, through two inputs, the outputs of a single model and expand to multiple inputs and multiple outputs model, the fixed pay scale under the assumption that using linear programming method, the production border and to assess each unit for the relative efficiency, the law is known as the DEA model CCR. Suppose k DMUs, each DMU k $(\mathrm{k}=1, \ldots, \mathrm{N})$ Using the $M$ input species $\chi_{i k}(i=1, \ldots, m, k=1, \ldots$, N) $>0$, Production $n$ outputs $y_{r k}(r=1, \ldots, n, k=1, \ldots$, $\mathrm{N})>0$, As can be in a DMU $k$ expected that the efficiency values are as follows:

$$
\begin{array}{ll}
\operatorname{Max} \quad \mathrm{H}_{\mathrm{k}}=\frac{\sum_{\mathrm{r}=1}^{\mathrm{n}} \mathrm{u}_{\mathrm{r}} \mathrm{y}_{\mathrm{rk}}}{\sum_{\mathrm{i}=1}^{\mathrm{m}} \mathrm{v}_{\mathrm{i}} \chi_{\mathrm{ik}}} \\
\text { subject to } \quad \mathrm{H}_{\mathrm{k}}=\frac{\sum_{\mathrm{r}=1}^{\mathrm{n}} \mathrm{u}_{\mathrm{r}} \mathrm{y}_{\mathrm{rk}}}{\sum_{\mathrm{i}=1}^{\mathrm{m}} \mathrm{v}_{\mathrm{i}} \chi_{\mathrm{ik}}} \leq 1
\end{array}
$$

$\mathrm{y}_{\mathrm{rk}}=$ Amount of the rth output for the kth DMU

$\chi_{\mathrm{ik}}=$ Amount of the ith input for the kth DMU

$\mathrm{u}_{\mathrm{r}}=$ The weight assigned to the rth output

$\mathrm{v}_{\mathrm{i}}=$ The weight assigned to the ith input

$\varepsilon=$ Non-archimedean quantity, is arbitrary small positive values

Because Eq.1 to scores-planning (Fractional programming) model is not easy to solve, Charnes et al. ${ }^{[2]}$ to be converted to linear programming (Linear programming) model, as follows:

$$
\operatorname{Max} \quad \mathrm{H}_{\mathrm{k}}=\sum_{\mathrm{r}=1}^{\mathrm{n}} \mathrm{u}_{\mathrm{r}} \mathrm{y}_{\mathrm{rk}}
$$

subject to $\sum_{\mathrm{r}=1}^{\mathrm{n}} \mathrm{u}_{\mathrm{r}} \mathrm{y}_{\mathrm{rk}}-\sum_{\mathrm{i}=1}^{\mathrm{m}} \mathrm{v}_{\mathrm{i}} \chi_{\mathrm{ik}} \leq 0$

$$
\mathrm{u}_{\mathrm{r}}, \mathrm{v}_{\mathrm{i}} \geq \varepsilon ; \mathrm{i}=1, \cdots, \mathrm{m} ; \mathrm{r}=1, \cdots, \mathrm{n} ; \mathrm{k}=1, \cdots, \mathrm{N}
$$

Formula (2) at the input items portfolio weighted average value of the one cases, the items for output weighted average portfolio maximum efficiency is used to indicate the relative value. But its limitations-the number $(\mathrm{n}+\mathrm{k}+\mathrm{m}+\mathrm{l})$ was significantly more than the number of variables $(\mathrm{n}+\mathrm{k})$, can use dual conversion pairs (Duality) mode, reducing restrictions on the number of convenience-type solution, as follows:

$$
\begin{aligned}
& \text { Min } \mathrm{H}_{\mathrm{k}}=\theta_{\mathrm{k}}-\varepsilon \geq\left(\sum_{\mathrm{i}=1}^{\mathrm{m}} \mathrm{S}_{\mathrm{ik}}^{-}+\sum_{\mathrm{r}=1}^{\mathrm{n}} \mathrm{S}_{\mathrm{rk}}^{+}\right) \\
& \text {subject to } \sum_{\mathrm{k}=1}^{\mathrm{N}} \lambda_{\mathrm{k}} \chi_{\mathrm{ik}}-\theta_{\mathrm{k}} \chi_{\mathrm{ik}}+\mathrm{S}_{\mathrm{ik}}^{-}=0 \\
& \sum_{\mathrm{k}=1}^{\mathrm{N}} \lambda_{\mathrm{k}} \chi_{\mathrm{ik}}-\mathrm{S}_{\mathrm{rk}}^{+}=\mathrm{y}_{\mathrm{rk}} \\
& \varepsilon, \lambda_{\mathrm{k}}, \mathrm{S}_{\mathrm{ik}}^{-}, \mathrm{S}_{\mathrm{rk}}^{+} \geq 0 ; \mathrm{i}=1, \cdots, \mathrm{m} ; \mathrm{r}=1, \cdots, \mathrm{n} ; \mathrm{k}=1, \cdots, \mathrm{N}
\end{aligned}
$$

Formula (3) $\mathrm{S}_{\mathrm{ik}}^{-}, \mathrm{S}_{\mathrm{ik}}^{+}$and $\lambda_{\mathrm{k}}$ for all DMU and the best allocation of DMU combination of linear equations, the weights $\theta$ efficiency of a practical value. $\mathrm{S}_{\mathrm{ik}}^{-}$and $\mathrm{S}_{\mathrm{ik}}^{+}$are the input and output variables variance (Slack Variable), the representative of the actual value and the best efficiency of the difference between the value that can be used to understand the inputs and outputs of the number of room for improvement. When $\theta=1$, $\mathrm{S}_{\mathrm{ik}}^{-}=\mathrm{S}_{\mathrm{ik}}^{+}=0$, the DMU said relatively efficient. When DMU relative efficiency and can be adjusted through the following and achieving optimum efficiency goals:

$$
\chi_{\mathrm{ik}}^{*}=\theta_{\mathrm{k}}^{*} \chi_{\mathrm{ik}}-\mathrm{S}_{\mathrm{ik}}^{-*}
$$

\section{RESULTS AND DISCUSSION}

This study used database analysers for the years 2004-2006 for the input and output information for the CCR model to analyse the operational efficiency (stage I) and profitability efficiency (Stage II) of banks. In addition, the Anderson and Peterson (A and P) mode was applied, respectively, to the first and second phases of the efficiency of the banks assessed. The results of the analysis on the two stages of the relative efficiency of the banking values, reference groups and $\mathrm{A}$ and $\mathrm{P}$ efficiency values of sequencing are shown in Table 3 and 4 . The efficiency values for stage one showed that the eighteen banks were relatively efficient, based on benchmark levels. If the value was less than efficient, with in the same industry is low level the relative efficiency. The efficiencies of the banks used in the reference groups set this benchmark. For example, 
HSBC bank was used in the reference group for the first stage of operational efficiency. This group also included HSBC and Public Bank. In regard to the study on the efficiency of banks, the A and P model, which estimates $\mathrm{A}$ and $\mathrm{P}$ efficiency value, states that the efficiency of its value is greater than one. However, the higher efficiency values expressed are in comparison to other banks, which had higher efficiency performance levels, as shown in the Table 3 and Table 4 rankings. While the A and P levels were based on efficiency values, in Table 4, the various phases of the operation were shown to have an average overall efficiency value of 0.94 , with a standard deviation of 0.07 , showing the gap between the greatest efficiency levels.

Figure 2 shows that, with the exception of Public (the 8th DMU) which had a difference between the two-stage efficiency and the traditional one-stage efficiency of close to 0 , all the banks analysed had a significant difference between their operational and profitability efficiencies. This study also calculates the absolute value of the difference between the operational and profitability stage efficiencies. This absolute value can be used to indicate differences between the twostage efficiencies; the bigger the absolute value, the better the two-stage DEA method is for indicating advantages or disadvantages compared to the one-stage DEA method ( Fig. 2). For example, in the two stage division of China CITIC (the 11th DMU), the difference between the operational and profitability efficiencies can be as high as $0.64(=1-0.36)$. This suggests that although China CITIC may have an operational advantage, it is extremely inefficient in the Other Income and Interest Revenue aspects.

In Table 5, the mean scores of operational and profitability models were 0.51 and 0.94 , respectively.

Table 3: Operational efficiency ranking (2004-2006)

\begin{tabular}{lllllr}
\hline & & \multicolumn{3}{c}{ Reference } & A and \\
No. & Bank & CCR & groups & P & Ranking \\
\hline D1 & HSBC & 1.00 & D1 D8 & 1.61 & 1.0 \\
D2 & Hang Seng & 0.74 & D1 & 0.74 & 3.0 \\
D3 & East Asia & 0.38 & D1 D8 & 0.38 & 14.0 \\
D4 & Wing Lung & 0.46 & D1 D8 & 0.46 & 6.5 \\
D5 & CITIC Ka Wah & 0.46 & D1 D8 & 0.46 & 6.5 \\
D6 & Wing Hang & 0.44 & D1 D8 & 0.44 & 8.5 \\
D7 & ICBC (Asia) & 0.43 & D1 D8 & 0.43 & 10.0 \\
D8 & Public & 1.00 & D1 D8 & 1.15 & 2.0 \\
D9 & Fubon & 0.44 & D1 D8 & 0.44 & 8.5 \\
D10 & China construction & 0.39 & D1 D8 & 0.39 & 13.0 \\
D11 & China CITIC & 0.36 & D1 D8 & 0.36 & 16.5 \\
D12 & Chong Hing & 0.40 & D1 D8 & 0.40 & 12.0 \\
D13 & ICBC & 0.37 & D1 D8 & 0.37 & 15.0 \\
D14 & Dah Sing & 0.49 & D1 D8 & 0.49 & 5.0 \\
D15 & China & 0.41 & D1 D8 & 0.41 & 11.0 \\
D16 & Standard chartered & 0.67 & D1 D8 & 0.67 & 4.0 \\
D17 & Communications & 0.36 & D1 D8 & 0.36 & 16.5 \\
D18 & Cmbchina & 0.34 & D1 D8 & 0.34 & 18.0 \\
& Mean & 0.51 & & & \\
& SD & 0.20 & & & \\
\hline
\end{tabular}

The Table 5 shows that six of the banks were efficient in the profitability performance model. From the result of the mean efficiency score, we can conclude that profitability performance was better than operational performance for these eighteen banks. The operational model showed that large and old banks were more efficient than the small and new banks (Table 6). The profitability model results showed that large banks were more likely to generate revenue profit. The Large indicates that the total assets score is above the median and small means that the total assets score is below the median, Date established in 1940 prior to is the Old and in 1940 after is the New.

This result also reveals that banks are facing a highly competitive environment in Hong Kong. On the other hand, the large-sized banks are relatively TE in the profitability, suggesting that large-sized banks have used managerial expertise to operate banks in an efficiently manner.

Table 4: Profitability efficiency ranking (2004-2006)

\begin{tabular}{lllllc}
\hline & & Reference & A and \\
No. & Bank & CCR & groups & P & Ranking \\
\hline D1 & HSBC & 0.80 & D15 & 0.80 & 17.0 \\
D2 & Hang Seng & 1.00 & D2 D15 & 1.58 & 1.0 \\
D3 & East Asia & 0.93 & D15 D17 & 0.93 & 11.0 \\
D4 & Wing Lung & 0.89 & D2 D15 & 0.89 & 14.0 \\
D5 & CITIC Ka Wah & 0.93 & D15 D17 & 0.93 & 11.0 \\
D6 & Wing Hang & 0.88 & D8 D10 D15 & 0.88 & 15.5 \\
D7 & ICBC (Asia) & 0.93 & D15 D17 & 0.93 & 11.0 \\
D8 & Public & 1.00 & D8 D10 D15 & 1.02 & 4.0 \\
D9 & Fubon & 0.99 & D15 D17 & 0.99 & 7.0 \\
D10 & China construction & 1.00 & D10 D15 D17 & 1.00 & 6.0 \\
D11 & China CITIC & 1.00 & D10 D11 D17 & 1.01 & 5.0 \\
D12 & Chong Hing & 0.97 & D15 D17 & 0.97 & 9.0 \\
D13 & ICBC & 0.96 & D10 D15 D17 & 0.96 & 10.0 \\
D14 & Dah Sing & 0.88 & D10 D15 D17 & 0.88 & 15.5 \\
D15 & China & 1.00 & D10 D15 D17 & 1.15 & 2.0 \\
D16 & Standard chartered & 0.75 & D15 D17 & 0.75 & 18.0 \\
D17 & Communications & 1.00 & D10 D15 D17 & 1.06 & 3.0 \\
D18 & Cmbchina & 0.98 & D15 D17 & 0.98 & 8.0 \\
& Mean & 0.94 & & & \\
& SD & 0.07 & & & \\
\hline
\end{tabular}

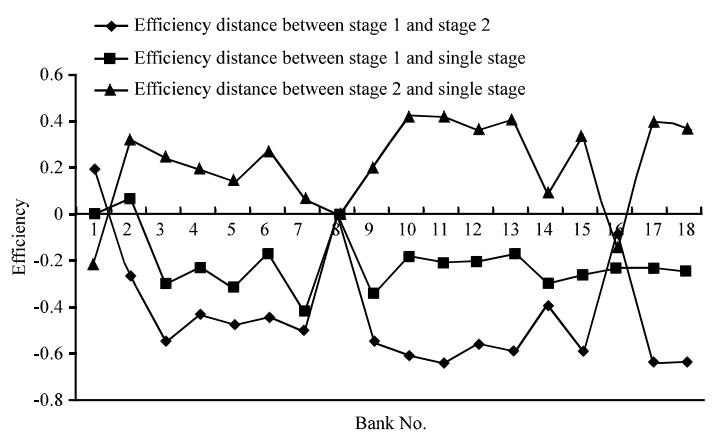

Fig. 2: Efficiency distance between two stage and single stage 
J. Social Sci., 4 (4): 280-287, 2008

Table 5: Efficiency scores of banks performance models

\begin{tabular}{llcccc}
\hline No & Bank & Operational TE & Profitability TE & Size & Date established \\
\hline D1 & HSBC & 1.00 & 0.80 & Large & Old \\
D2 & Hang Seng & 0.74 & 1.00 & Small & New \\
D3 & East Asia & 0.38 & 0.93 & Small & Old \\
D4 & Wing Lung & 0.46 & 0.89 & Small & Old \\
D5 & CITIC Ka Wah & 0.46 & 0.93 & Old \\
D6 & Wing Hang & 0.44 & 0.88 & Small & Old \\
D7 & ICBC(Asia) & 0.43 & 0.93 & Small & New \\
D8 & Public & 1.00 & 1.00 & Small & New \\
D9 & Fubon & 0.44 & 0.99 & Small & New \\
D10 & China construction & 0.39 & 1.00 & Large & New \\
D11 & China CITIC & 0.36 & 1.00 & Small & Sew \\
D12 & Chong Hing & 0.40 & 0.97 & Small & Old \\
D13 & ICBC & 0.37 & 0.96 & Small & New \\
D14 & Dah Sing & 0.49 & 0.88 & Small & Old \\
D15 & China & 0.41 & 0.00 & Small & Old \\
D16 & Standard chartered & 0.67 & 1.00 & Large & Old \\
D17 & Communications & 0.36 & 0.98 & Small & New \\
D18 & Cmbchina & 0.34 & 0.94 & & \\
& Mean & 0.51 & & & \\
\hline
\end{tabular}

Table 6: Summary statistics: TE of size and date established

\begin{tabular}{|c|c|c|c|c|c|c|c|}
\hline \multirow[b]{2}{*}{ Category } & \multirow{2}{*}{$\begin{array}{l}\text { No. } \\
\text { banks }\end{array}$} & \multicolumn{3}{|c|}{ Operational } & \multicolumn{3}{|c|}{ Profitability } \\
\hline & & Mean & M-W U (p-value) & $\mathrm{K}-\mathrm{W} \chi^{2}$ (p-value) & Mean & M-W U (p-value) & $\mathrm{K}-\mathrm{W} \chi^{2}$ (p-value) \\
\hline \multicolumn{8}{|l|}{ Size } \\
\hline Large & 4 & 0.530 & -0.851 & 0.725 & 0.940 & -0.434 & 0.188 \\
\hline Small & 14 & 0.501 & $(0.221)$ & 0.395 & 0.938 & $(0.360)$ & $(0.664)$ \\
\hline \multicolumn{8}{|c|}{ Date established } \\
\hline Old & 10 & 0.560 & -0.890 & 0.793 & 0.910 & -1.270 & 1.614 \\
\hline New & 8 & 0.450 & $(0.204)$ & $(0.373)$ & 0.970 & $(0.237)$ & $(0.204)$ \\
\hline
\end{tabular}

Table 7: Four combinations from two kinds of efficiencies

\begin{tabular}{llll}
\hline No. & OE & PE & Bank name \\
\hline 1 & High & High & Hang Seng, Public \\
2 & High & Low & HSBC, Standard chartered \\
3 & Low & High & Fubon, China construction, China CITIC, Chong Hing, ICBC, China, communications, Cmbchina \\
4 & Low & Low & East Asia, Wing Lung, CITIC Ka Wah, Wing Hang, ICBC (Asia), Dah Sing \\
\hline
\end{tabular}

To summarize the above results, regardless of the banks size, the economies of scale are insufficient and banks should consider benefits programs. Banks must identify the input/output values that are most important, or distinguish the banks, which can be treated as benchmarks. Ranking lists of the operational and profitability models of all the efficient banks will be given.

Table 7 shows that two banks are in the stars category, characterized by high $\mathrm{OE}$ and high PE. Conversely, six banks are characterized by low OE and low PE (groups 1 and 4). It can be argued that group 4 banks should rearrange their inputs in order to improve their performance. Group 3, which includes eight banks, shows characteristics of low OE and high PE, indicating that their bank services (outputs) were unable to meet market demand. By using Table 7 to further distinguish the important differences between the operational and profitability efficiencies, a crosstabulation is presented in Fig. 3 .

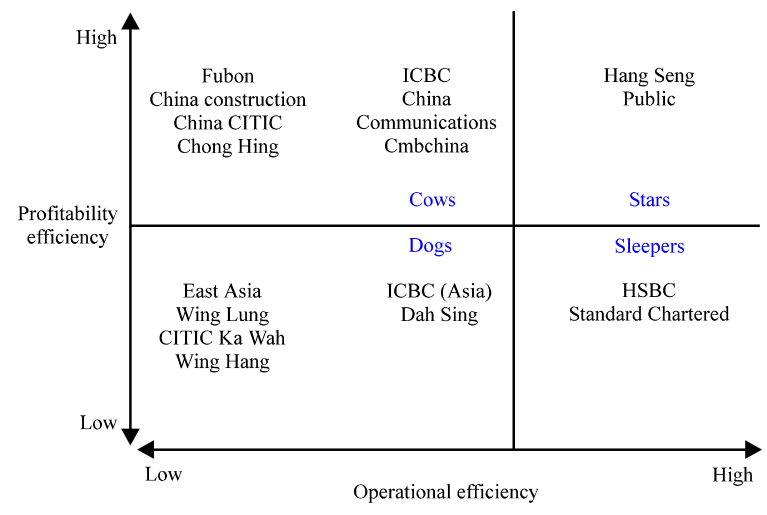

Fig. 3: Profitability $\mathrm{x}$ operational efficiency crosstabulation

In Fig. 3 the operational and profitability $\mathrm{TE}$ provide a two-by-two matrix to classify the banks, which fell into four quadrants: stars, cows, sleepers and 
dogs, which are similar to the classifications done by the boston consulting group. Splitting them in half using the median created high and low groups of operational and profitability efficiencies. The banks in each of the groups are summarized as follows:

- High operational and profitability efficienciesthese banks included: the China Development, Hang Seng and Public banks. They should keep their strength in the operational and profitability stages by occasionally justifying their strategies of Total Deposits, Gross Loans, Other Income, Interest Revenue, Pre-Tax Income and Total Assets. These banks appear to be good role models and can be treated as benchmarks by others.

- Low operational and profitability efficiencies-these banks can increase their business or the sales of products to get more income and reduce bank loans, so as to increase their profitability opportunities

- High operational efficiency and low profitability efficiency-these banks can increase their operating efficiency with more Interest Revenue, so as to increase their profitability opportunities

- High profitability efficiency and low operational efficiency-to reduce the amount of loans and increase revenue, these banks can improve banking operations. An increase in the sales of goods or services will increase income. They should also continue to maintain their high profitability efficiency

Managerial implications: From this analysis, it appears that each of the banks has its own advantages and disadvantages when it comes to operational and profitability efficiencies. The good and poor performances among the banks can be divided into four types, in each of which different strategies are likely to enhance business efficiency (Fig. 3).

Strategies for companies with better operational and profitability capabilities: The operational and profitability efficiencies of these banks were above the medians for the banks. The banks that belong in this category include: the Hang Seng and Public banks. Out of these, Hang Seng bank had the best profitability efficiency (an efficiency value of 1). These two banks attempt to maintain their operational advantages while also trying to enhance their profitability strategies (raise revenue to increase their profitable opportunities). Other banks should simultaneously improve their operational and profitability strategies (business expansion to increase revenue, or reduce loans to increase profitable opportunities.) Strategies for companies with lower operational and profitability efficiencies: the operational and profitability capabilities of these banks were below the medians for all the banks. The banks that belong in this category include: East Asia, Wing Lung, CITIC Ka Wah, Wing Hang, ICBC (Asia) and Dah Sing Bank. These banks should try to strengthen their operational and profitability efficiencies.

Strategies for banks with better operational efficiency, yet poorer profitability efficiency: banks that belong in this category have an operational efficiency above the industry median standard, yet their profitability efficiency is below the mean value. Examples of these banks are: HSBC and Standard Chartered. These banks have good operational efficiency but poor profitability efficiency, suggesting that these companies should particularly improve their profitability strategies (increase their operating efficiency with more interest revenue, so as to increase their profitability opportunities). The other eight banks, Fubon, China Construction, China CITIC, Chong Hing, ICBC, China, Communications and Cmbchina should strengthen their operational strategies while also adjusting their profitability strategies.

\section{CONCLUSION}

We included two models, operational efficiency and profitability efficiency, with DEA analysis of the efficiency levels of twenty-three banks for the years 2004-2006. The results of this study show that the twostage DEA method of analysis can better indicate managerial efficiency and can help the banks at various stages to understand their specific advantages and disadvantages more thoroughly and clearly.

It is felt that these findings should provide practical help to banks by showing them how to change their strategies to suit their particular circumstances. The results of this study: Larger older banks are generally more efficient than small newer banks in the operational model. On the other hand, smaller banks are classified into a zone of stars, including the Hang Seng and Public banks. This means that smaller banks have better competitive power than large ones.

Finally, Hong Kong's financial system will move toward business diversification and in the future, banks will continue to enhance their operating efficiency, which will be worthy of a follow-up study. Furthermore, this study was limited to the years 20042006. Follow-up research should expand the scope of time considered and other variables. 


\section{REFERENCES}

1. Bauer, P.W., A.N. Berger, G.D. Ferrier and D.B. Humphrey, 1998. Consistency conditions for regulatory analysis of financial institutions: A comparison of frontier efficiency methods. J. Econ. Business, 50: 85-114. DOI: 10.1016/S01486195(97)00072-6.

2. Charnes, A., W.W. Cooper and E. Rhoades, 1978. Measuring the efficiency of decision making units. Eur. J. Operat. Res., 2: 429-444. DOI: 10.1016/0377-2217(78)90138-8.

3. Chen, T.Y. 2002. Measuring firm performance with DEA and prior information in Taiwan's banks. Appl. Econ. Lett., 9:201-204. DOI: 10.1080/13504850110057947.

4. Farrell, M., 1957. The measurement of productive efficiency. J. R. Stat. Soc. Gen., 120: 253-281. DOI: $10.2307 / 2343100$

5. Grifell Tatje, E. and C.A. Knox Lovell, 1999. Profits and productivity. Manage. Sci., 45: $\quad$ 1177-1193. http://direct.bl.uk/bld/PlaceOrder.do?UIN=068588 856\&ETOC $=$ RN\& from $=$ searchengine.

6. Halkos, G.E. and D.S. Salamouris, 2004. Efficiency measurement of the Greek commercial banks with the use of financial ratios: A data envelopment analysis approach. Manage. Account. Res., 5: 201-224. DOI:10.1016/j.mar.2004.02.001.

7. Kao, C. and S.T. Liu, 2004. Predicting Bank Performance with Financial Forecasts: A case of Taiwan commercial banks. J. Bank. Finan., 28: 2358-2368. DOI: 10.1016/j.jbankfin.2003.09. 008.

8. Lo, S.F. and W.M. Lu, 2006. Does size matter? Finding the profitability and marketability benchmark of financial holding companies. Asiapacific J. Operat. Res., 23: 229-246. http://ideas.repec.org/a/wsi/apjorx/v23y2006i02p2 29-246.html.

9. Luo, X., 2003. Evaluating the profitability and marketability efficiency of large banks An appl. of data envelopment anal. J. Bus. Res., 56: 627-635. DOI: 10.1016/S0148-2963(01)00293-4.
10. Lozano, V.A., J.T. Pastor and J.M. Pastor, 2002. An efficiency comparison of European banking system operating under different environmental conditions. J. Product. Anal., 18: 59-77. DOI: 10.1023/A:1015704510270.

11. Manandhar, R. and J.C.S. Tang, 2002. The evaluation of bank branch performance using data envelopment analysis: A framework. J. High Technol. Manage. Res., 13: 1-17. DOI: 10.1016/S1047-8310(01)00045-1.

12. Oral, M., O. Kettani and R. Yolalan, 1992. An empirical study on analysis the productivity of bank branches. IIE Trans., 24: 166-176. DOI: 10.1080/07408179208964257.

13. Sathye, M., 2003. Efficiency of banks in a developing economy: The case of India. Eur. J. Operat. Res., 148: 662-671. DOI: 10.1016/S03772217(02)00471-X.

13. Sathye, M., 2001. X-efficiency in Australian banking: An empirical investigation. J. Bank. Finan., 25: 613-630. DOI: $10.1016 / \mathrm{S} 0378-$ 4266(00)00156-4.

15. Seiford, L.M. and J. Zhu, 1999. Profitability and marketability of the top 55 us commercial banks. Manage. Sci., 45: 1270-1288. http://portal.acm. org/citation.. fm? $\mathrm{id}=333426$.

16. Siems, T., 1992. Quantifying management's role in bank survival. Econ. Rev. Fed. Reserve Bank Dallas, 1: 29-50. http://ideas.repec.org/a/fip/fedder/y1992iqip2941.html.

17. Soteriou, A. and S.A. Zenios, 1999. Operations, quality and profitability in the provision of banking services. Manage. Sci., 45: 1221-1238. DOI: 10.1287/mnsc.45.9.1221.

18. Zhu, J., 2000. Multi-factor performance measure model with an application to fortune 500 companies. Eur. J. Operat. Res., 123: 105-124. DOI: 10.1016/S0377-2217(99)00096-X.

19. Zhu, J. and Z.H. Shen, 1995. A discussion of testing DMUs' returns to scale. Eur. J. Operat. Res., 81: 590-596. DOI: 10.1016/S03772217(96)00207-X. 